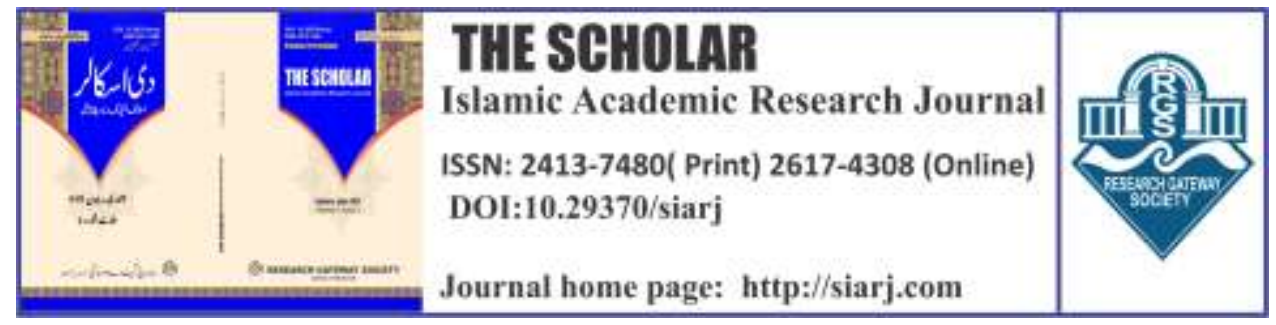

\title{
THE RIGHTS AND DUTIES OF MINORITIES IN ISLAMIC WELFARE STATE AND ITS IMPLEMENTATION IN THE CONTEMPORARY WORLD
}

\section{Saad Jaffar}

Lecturer of Islamic studies, Department of Pakistan Studies, Abbottabad University of Science and Technology, Abbottabad. Email: SaadJaffar@aust.edu.pk

\section{ORCID ID:}

https://orcid.org/ 0000-0003-3438-9360

\section{Muhammad Ayaz}

Education Officer, QAED (M) Bahawalpur.

Email: aayaz.te.bwp@gmail.com

\section{Nasir Ali khan}

Assistant prof, COMSATS, University Islamabad, Abbottabad campus

Email: Nasirali@ cuiatd.edu.pk

\section{ORCID ID:}

https://orcid.org/ 0000-0002-2377-8101

ORCI D ID: https://orcid.org/ 0000-0002-3250-4559

To cite this article:

Jaffar, Saad, Nasir Ali Khan, and Muhammad Ayaz. "THE RIGHTS AND DUTIES OF MINORITIES IN ISLAMIC WELFARE STATE AND ITS IMPLEMENTATION IN THE CONTEMPORARY WORLD." The Scholar-Islamic Academic Research Journal 7, No. 2 (December 29, 2021).

To link to this article: https://doi.org/10.29370/siarj/issue13ar3

\begin{tabular}{|c|c|}
\hline Journal & $\begin{array}{l}\text { The Scholar Islamic Academic Research Journal } \\
\text { Vol. 7, No. } 2 \text { ||July -December } 2021 \text { || P.36- } 57\end{array}$ \\
\hline Publisher & Research Gateway Society \\
\hline DOI: & 10.29370/siarj/issue13ar3 \\
\hline URL: & https://doi.org/10.29370/siarj/issue13ar3 \\
\hline License: & Copyright c 2017 NC-SA 4.0 \\
\hline Journal homepage & www.siarj.com \\
\hline Published online: & $2021-12-29$ \\
\hline
\end{tabular}
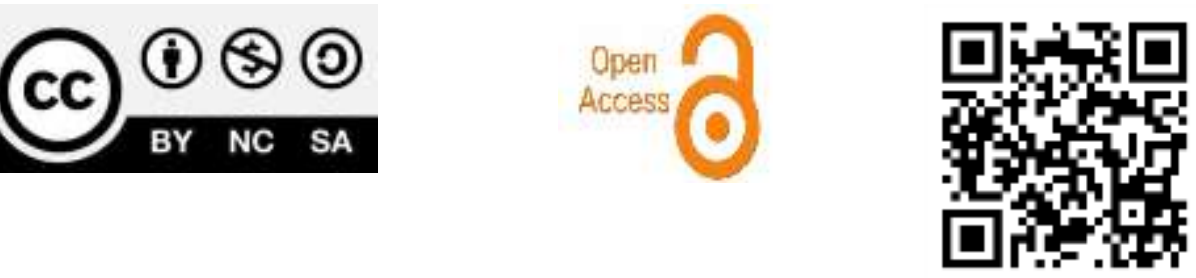
THE SCHOLAR (July-December 2021)

\title{
THE RIGHTS AND DUTIES OF MINORITIES IN ISLAMIC WELFARE STATE AND ITS IMPLEMENTATION IN THE CONTEMPORARY WORLD
}

\author{
Saad Jaffar, Nasir Ali khan, Muhammad Ayaz
}

\begin{abstract}
:
Islam is the only DEEN that teaches about the upright and welfare of all creatures in the universe. The Islamic Welfare State is considered a complete state in a sense that all citizens are given equal rights in the light of Quran and Sunnah. Minorities also have equal rights and duties as well as all forms of facilities which the majority has. Minorities enjoy all human rights in an Islamic Welfare State. They live in peace in a welfare state and are equally punished for breaking the law. They have equal rights of protection, purchasing and selling of property. Providing employment to the poor and vulnerable minorities and helping them is one of the responsibilities of the welfare state. At present, the situation of implementation of the rights of minorities needs much improvement. Current research has mainly been conducted through primary and secondary sources including Holy Quran, Hadith, and sayings of jurists, available published papers and documents from offices, archives and libraries. The research revealed the rights and duties of minorities in an
\end{abstract}


THE SCHOLAR (July-December 2021)

Islamic welfare state in the light of Quran and Hadith and also highlighted

their practical forms in the present time.

KEY WORDS: Islam, Minorities, Rights, duties, Welfare State, jurists, Quran-o-Sunnat.

\section{INTRODUCTION:}

Allah Almighty has linked the welfare of humanity with Islam. Islamic law is for the welfare of those, who believe in it as well as for those who don't believe in it. The Islamic welfare state upholds all rights related to religious duties and worship, as well as the discipline of politics and the fundamental rights of citizens. The Islamic welfare state, commands good conduct of non-Muslims, who do not fight against Islam and Muslims. The state instructs to be kind and tolerant, towards them. An Islamic welfare state is a state that is subject to the laws of the Quran and Sunnah. Teachings of Quran and Sunnah are clear about every aspect of life in the same way it is clear about minorities. In an Islamic welfare state, all nonMuslim minorities enjoy all kinds of freedom, whether it is a matter of faith or religion, as human beings, they are equal partners with Muslims in terms of freedom and fundamental rights and all are treated equally in eyes of law. As human beings, there is no difference between them. They have same duties as a Muslim does and they are entitled to the basic rights just like a Muslim deserves. Among the rights enjoyed by minorities in a welfare state, the most important and necessary right is the right to live. The welfare state is responsible for protecting lives of both Muslims and Non-Muslims in an equal manner. The state is responsible of the lives as well as protection of assets of the minorities.

Islamic Welfare state protects the assets of minorities like that of a 
Muslims, it does not seize their property or assets, even if they do not pay Jizya, and their property will not be forcibly sold. The state protects the honour and dignity of all non-Muslims, it is the responsibility of the state to protect them and provide legal and judicial protection. In the eyes of law, both are equal, the punishments and boundaries for Muslims are the same as for the non-Muslims. Both are equal according to Qiyas and Diyat. Similarly, it is the responsibility of the Islamic welfare state to help those in need among non-Muslim minorities. Apart from obligatory charity (zakat), the state helps those in necessity, in every possible way. All the above mentioned rights belong to minorities in an Islamic welfare state. No individual has the right to deprive them of any of these rights; there are also some duties that are obligatory on them. In the Islamic Welfare State, a specific term is used for Non-Muslim minorities; they are also called Ahl-e-Zimah or Zimi.

According to the dictionary, the word Zimi:

$$
\text { " من ذمة وهي لغة العهد والأمان"1 }
$$

Zimmah means covenant, responsibility, order, safety and security.

And the term Zimmah literally mean:

$$
\text { "أهل الذّمّة (وهم اليهود والنصارى) التي تدفع الجزية للدولة الإسلامية مقابل حمايتها }
$$

${ }^{1}$ Zubaidi,Muhammad bin Muhammad Abdurazaq Alhussaini, Abul Faiz,Tajul uroos,V. 32, P. 203

${ }^{2}$ Hashmi, Salih bin Husaain Jahfari, Min hur fir Torat wal Injeel,Publisher Alhabikan Riaz, V. 1,P.123 
Zimmi are those people who are in contract with the Islamic state, (they are the Jews and Christians) who pay Jizya to the Islamic state in return for its protection and enjoyment of its religious freedom under Islamic tolerance. The non-Muslim minorities in the welfare state have been given this name because according to Allah, His Prophet and all the Muslim community, they have been granted an agreement, which helps them to have safe lives in the society. The non-Muslim minority, is guaranteed a safe life in a Muslim society, under the agreement with the Muslims. They have all the rights that a Muslim enjoys and they are protected in the same manner. All mighty Allah says in the Holy Quran:

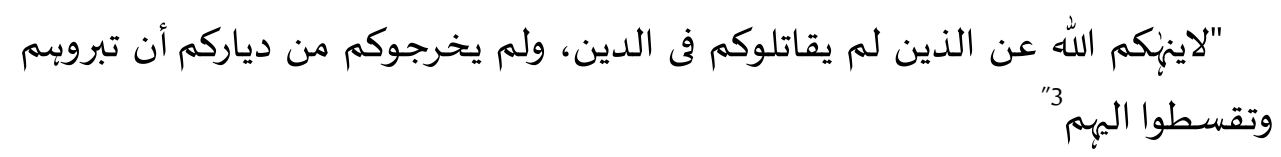

"Allah does not forbid you from those who do not fight you because of religion and do not expel you from your homes - from being righteous toward them and acting justly toward them. Indeed, Allah loves those who act justly"

Allah Almighty does not have any animosity towards non-Muslims nor does He command us to fight the disbelievers in all circumstances but the fact is that Allah commands us to treat the minorities well. And $\mathrm{He}$ commands us to do well with them and does not forbid us to do justice with them. The welfare state is the name of peace loving state; this is the

${ }^{3} 2$ :Al-Quran:60/2 
lesson to be learned from the teachings of the Quran and Sunnah, which are the foundation of a welfare state.

In another place in Holy Quran the All mighty Allah says:

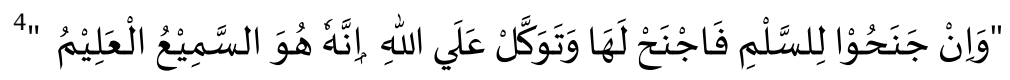

"But if they incline to peace, you also incline to it, and (put your) trust in

Allah. Verily, He is the All-Hearer, the All-Knower".

In this verse, it is taught that if you continue to take outward measures under the command of Allah and see your opponents bowing down, then you too are inclined to peace. But put your true trust in Allah, for every command of His is based on expediency. He knows the outward appearance of His followers and also the inner self. So nothing is hidden from Him.

It's the saying of Holy Prophet:

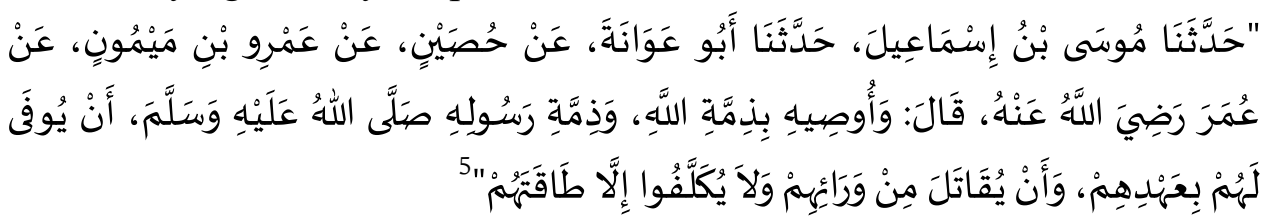

"those who are entrusted with the responsibility of Allah and His

Messenger that they should abide by the covenant which has been made with them; and fight for their defense and do not burden them beyond their limits".

\section{${ }^{4}$ Al-Quran:8/61}

5 Bukhari,Muhammad bin Ismail,Al shahi Al Bukhari,Kitabul jihad,Publisher Toqu Najah,V4, P69,Hadith3052 


\section{The Rights and Duties of Minorities in Islamic Welfare State and}

Its Implementation in the Contemporary World

All the minorities living in the welfare state are entitled to all the privileges, as they live in accordance with the supremacy of law and the constitution Minorities. For example, they are exempted from defense services by paying a small amount of money in taxes and all their rights are the responsibility of the welfare state. The rights enjoyed by nonMuslim minorities can be further subdivided as given below:

1. Right to Protection of Life.

2. Right to Protection of Inheritance

3. Right to Protection of Honor and Dignity

4. Right to Protection of Religion

5. Right to help

\section{RIGHT TO PROTECTION OF LIFE}

The state ensures the protection of the lives of its minorities so that no one can harm them. The protection of their lives is the responsibility of the state. In the welfare state, both Muslims and non-Muslims are equal in their rights of protection. Giving equal protection and respect to its minorities and defend them from all forms of abuse is the state's top priority.

The Holy Prophet said that:

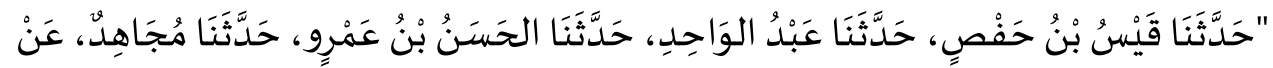

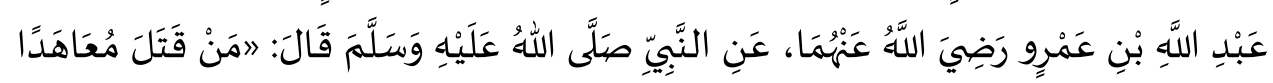

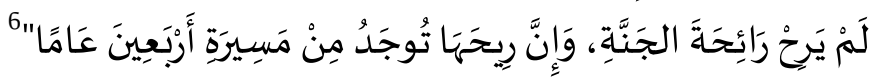

Whoever kills a covenant will not smell the fragrance of Paradise while its

${ }^{6}$ Shahi Al Bukhari:V.1,P448 


\section{The Rights and Duties of Minorities in Islamic Welfare State and}

Its Implementation in the Contemporary World

fragrance is found from the journey of forty years.

The importance of protecting the lives of minorities can be determined from the saying of the Holy Prophet Hazrat Muhammad (SAW) that if a Muslim, who deserves paradise on account of his good deeds, commit wrongful killing of a non-Muslim minority, he would not be able to smell the fragrance of paradise and will be deprived from its joy. The fragrance of heaven that reaches us, it reaches after travelling for forty years meaning the fragrance of heaven that will come from afar but the Muslim who kills the covenant will not be able to smell it either.

Another hadith mentions that the Holy prophet said:

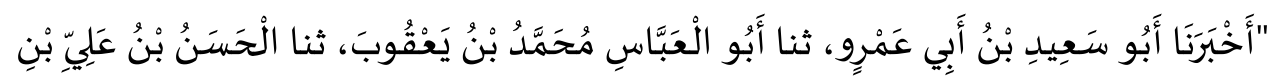

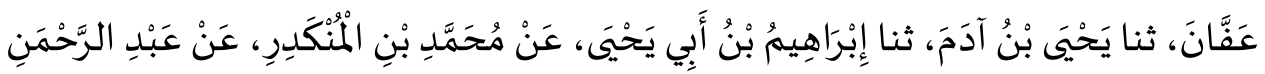

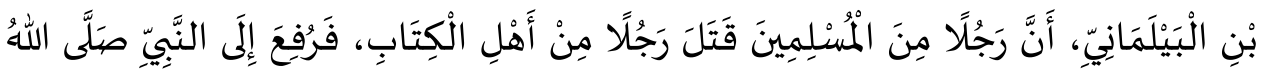

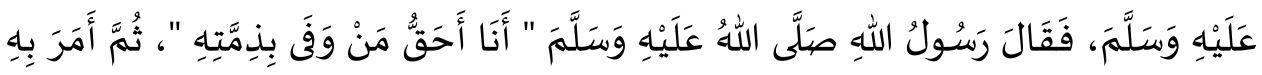
فَقَتُتِلَ"

When one of the Muslims killed a man from the covenant, the case was brought to the Prophet, peace be upon him. He said that "I am the most responsible one to deliver the trust of Zimmi," and then he killed that murderer.

The implementation of the teachings and laws of the Holy Prophet has

7 Bahiqi, Ali bin Musa Kharasani,Bahiqi,Kitabul Jirah,Publisher darul kutubul Ilmia Bairoot,V8,P56 Hadith,15918 


\section{The Rights and Duties of Minorities in Islamic Welfare State and}

Its Implementation in the Contemporary World

made non-Muslim minorities equal to the Muslims. This position attained in the Islamic welfare state is unparalleled in any other state in the world. The basic fundamental right that minorities have from the state is the right to assets. A welfare state protects the lives and assets of its minorities.

\section{RIGHT OF INHERITANCE}

The Islamic Welfare State protects the property of Zimmi's like Muslims, the government does not evict them, nor does the state seize their lands by force. Even if they do not pay the Jizya, the property will not be auctioned off. On the contrary, if something is taken from the minorities without their consent, then the promise of the Prophet Muhammad (SAW) is narrated.

The Holy Prophet said:

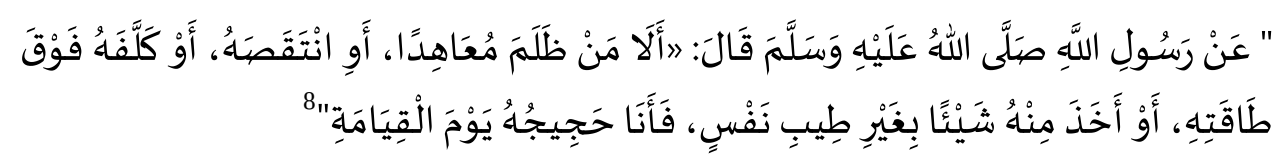

if a Muslim wrongs a covenant, or belittles him, or burdens him beyond his capacity, or takes something from him against his will, than I will fight against such a man.

In the light of Prophet (SAW)'s edict, it is concluded that no oppression of minorities can be imagined in a welfare state. If a person harms minorities or disposes off property without their permission, he deserves punishment in the eyes of state. According to the quote of Prophet Hazrat Muhammad

8 Abo Dawood,Sulaman bin Ashat,Sunnan abi dawood,Kitabul Khiraj, Publisher, ALmaktabtul Asria,Bairoot,V3,P170,Hadith 3052 


\section{The Rights and Duties of Minorities in Islamic Welfare State and Its Implementation in the Contemporary World}

(SAW), not only in this world, but he will appear in the court of Allah and the Holy Prophet will appear on behalf of this minority on the day of Resurrection and non-Muslim minority will get his dues. Non-Muslim minorities, like Muslims have the right to buy and sell, and also develop all means of livelihood, as well as the right to dispose of their property. If the amount of Jizya was due to a Zimmi and he died, it will not be received from his inheritance, nor will any pressure be put on his heirs to pay the Jizya.

The Holy Prophet said:

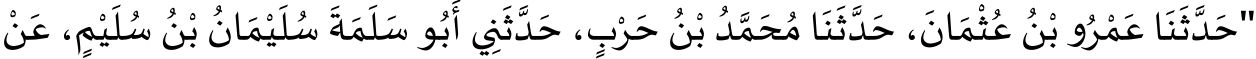

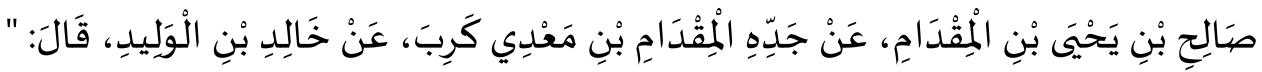

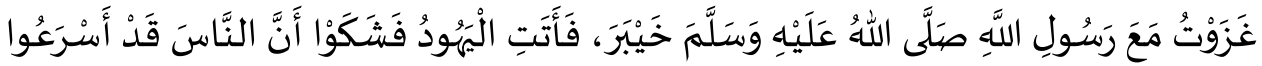

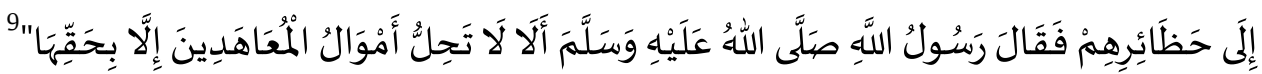
Allah's Messenger (- beware the assets of covenants are not halal without its rights.

The welfare state ensures that no one has the right to embezzle the property of Non-Muslims under any agreement just like that of Muslims. No one can dispose of the property of a non-Muslim minority because their property must be protected in the same way as it is done with any other person's wealth. A Muslim cannot dispose off another Muslim's property without permission, just as it is also not permissible to dispose of a non-Muslim's property.

The Islamic Welfare state gives non-Muslim minorities the full right to inherit. All Muslims agree that followers of one religion can inherit from each other because Muslim cannot inherit from a non-Muslim. A Christian

\footnotetext{
${ }^{9}$ Sunnan abi dawood:,V.3,P356,Hadith 3806
} 


\section{The Rights and Duties of Minorities in Islamic Welfare State and} Its Implementation in the Contemporary World

can inherit a Jew, while a Jew can inherit from Christian but a Muslim cannot inherit either, because the state gives non-Muslim minorities the right to own property, which gives them the right to full participation in the matter of its disposal, inheritance and they can also inherit their property.

In Quran Almighty Allah says:

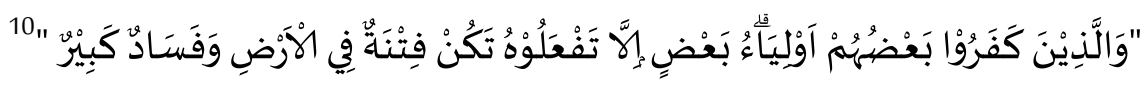

And those who disbelieve are the guardians of one another. Do not do friendship with them. There will be persecution on earth and great persecution. In the welfare state, this important task of distribution of inheritance has also taken into account. Just as man was created, i.e. obedience and worship of Almighty, in this sense, man has been declared as two separate nations in the whole world. These two national ideologies have established family ties to the extent of inheritance. No Muslim will get any share from Non-Muslim relative and no non-Muslim will have any right to inherit from a Muslim relative. On the bases of above mentioned concepts, the inheritance of non-Muslim minorities got security and after their deaths their inherited will be used by their community or Millat.

The Prophet, Hazrat Muhammad may God's prayers and peace be upon him, said about inheritance:

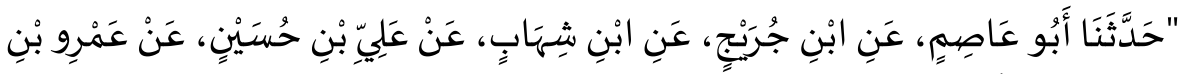

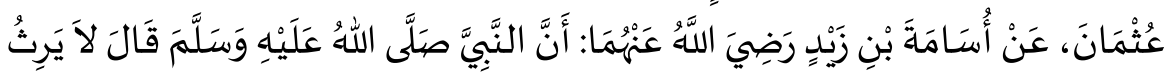

${ }^{10}$ Al-Quran:8/73 
A Muslim does not inherit an unbeliever, nor does an unbeliever inherit a

Muslim.

In addition, Umar said about Ashaat ibn Qais when he died:

Inheritance is given to the people of same religion.

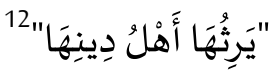

Ashat-bin-Qais was the uncle of Hazrat Umer and he did not convert to Islam so Hazrat Umer was not his heir but his property was divided among the relatives who were followers of his religion. These arguments prove that the non-Muslim minorities of the welfare state also have the right to inherit, to dispose and they can sell their lands and own them, their lands will not be taken by force. Rather a tribute (Karaj) will be taken from them, it cannot be increased and in return the promises made to nonMuslims will be fulfilled. No one has the right to take back any land from these non-Muslim minorities, it belongs to them.

\section{RIGHT TO PROTECTION OF HONOUR AND DIGNITY}

A Welfare State guarantees the protection of the honor and dignity of nonMuslim minorities. No citizen can be humiliated in a state. The state guarantees, protection of the honor and dignity of non-Muslim minorities. Just as attacking the honor of a Muslim is a crime, so is attacking the honor and dignity of a non-Muslim is a legitimate crime.

11 Bukhari,Muhammad bin Ismail,Kitabul Faraiz,Publisher Toqu Najah,V4,

P. 156,Hadith 6764

12 ibn qayem, Jozi , Mummad bin abu baker,Ahkamu ahluzimma, V. 2, P. 825 
The holy Prophet said:

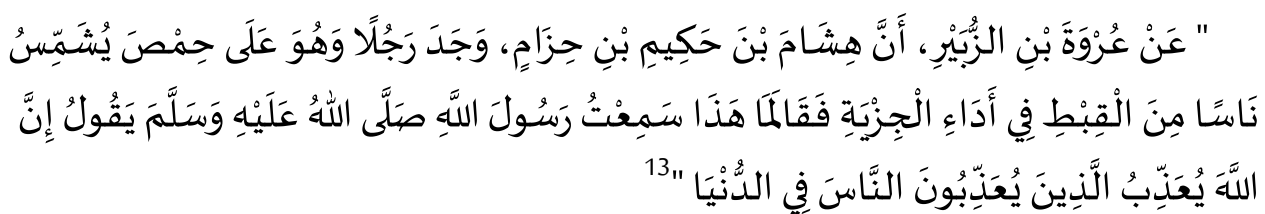

Hazrat Urwa narrated that Hisham ibn Hakim ibn Khazam found a man who was the governor of the city of Homs, he found him in such ay that he made a non-Muslim (qibti) stand under sun to collect Jizyah. Hisham said: hat is this, I have heard prophet saying that "Allah will surely punish those who torment people without any reason."

The Hadith also clarifies that if a person from a Non-Muslim minority cannot pay the jizya, then it is not permissible to despise him and he should not be treated badly because he is a human being, respect is must. With this saying of Holy Prophet (SAW), it is clear that, if a person insults a non-Muslim he deserves punishment in this world as well as in the hereafter. It is important not to gossip about a non-Muslim, to spy on their personal lives, to beat them or to abuse them.

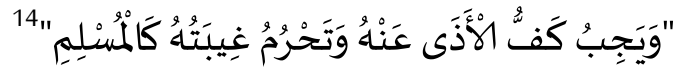

"It is obligatory to refrain from harming him, and his backbiting is as haraam as that of a Muslim"

In the Islamic welfare state, minorities enjoy judicial and legal protection, which is why they are guaranteed timely justice. The punishment that is given to Muslims for stealing, accusation or adultery, is also given to

13 Abo Dawood,Sulaman bin Ashat,Sunnan abi dawood,Kitabul Khiraj, V.3, P. 169, Hadith 3045

${ }^{14}$ Ibn Abideen, Abdul aziz abideen Aldamishqi,Radul Mukhtar,Publisher Darul fikr,V. 4, P.170 
The Scholar Islamic Academic Research Journal

Vol. 7, No. 2 || July-December 2021 || P. 36-57

https://doi.org/10.29370/siarj/issue13ar3

minorities.

\section{RIGHT TO PROTECTION OF RELIGION}

In the welfare state, Non-Muslim minorities have complete freedom and permission to practice their religious beliefs and rights. The state does not have the right to restrict religious freedom, demolish temples or other places of worship, and it is the responsibility of the state to protect all these places of worship. No one has the right to oppress any minorities or their religion or force them to change their religion.

In the holy Quran the all mighty Allah says that:

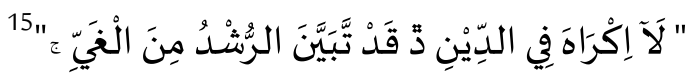

"There is no compulsion in religion. It has become clear from guidance and misguidance."

Deen is related to the reformation of the heart, and there is no room for coercion. Jizya is considered by some to be the essence of coercion in Islam, although if considered, it will be seen that the legitimacy Jizya is the opposite of it. It is in itself an argument that the real purpose is to prevail the real law of Islam and the government of Islam and not the individuals. Forcibly converting into Islam is prohibited and this is an example of our religion.

As it is clear from the History of Andalusian:

$$
\text { "إن الإندلام لم يكره فردًا على تغيير عقيدته، كما فعلت الصليبية على مدار التاريخ في }
$$

${ }^{15}$ Al-Quran:2/256

16 Jalhood,Abdullah bin Muhammad,Almowalat wal muhadat,Publisher,Darul Yaqeen, V. 2 P. 609 
The Scholar Islamic Academic Research Journal

Vol. 7, No. 2 || July-December 2021 || P. 36-57

https://doi.org/10.29370/siarj/issue13ar3

History of the Islamic welfare state is a witness that Muslims did not force any individual to change his faith and on the contrary, a study of history shows that the Muslims of Andalusia were forced by the Christians to convert

Narrated from Wahb bin Muslim Al Missiary:

$$
\text { "كان رسول الله بمكة عشر سنين لا يكره أحدا في الدين"17 }
$$

"The Prophet (peace and blessings of Allah be upon him) stayed in Madina for ten years and did not force anyone to convert".

In the welfare state, all settlements that are outside of the Islamic city have the complete freedom to procession and ringing of the bells. If their places of worship are damaged, they are repaired and new places of worship are also built. Non-Muslims are not allowed to hold religious processions in Muslim settlements on the days reserve for Muslim religious practices, although there is complete freedom inside places of worship. Non-Muslim minority can also establish religious schools for the education and training of their children and they will have the freedom to teach and proliferate their religion in a positive way.

Hazrat Umar bin Abdul Aziz asked Hazrat Hassan Bassri that:

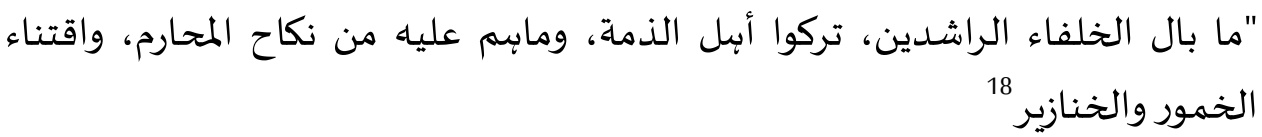

The Rightly Guided Caliphs( R.Z)has set non-Muslim minorities free in the matter of marriage with their mahrams and in the matter of alcohol and pork.

Hazrat Umar bin Abdul Aziz sought a fatwa from Hassan Basri regarding

17 Muslim Almisri, Abdullah bin wahb, Tafeer ul Quran minal jamih,Publisher darul gharbil islami,V,2 ,P.123

${ }^{18}$ Ibn qayem, Jozi,Mummad bin abu baker,Ahkamu Ahluzimah, V1, P 869 
The Scholar Islamic Academic Research Journal

Vol. 7, No. 2 || July-December 2021 || P. 36-57

https://doi.org/10.29370/siarj/issue13ar3

minorities asking that can minorities marry with their mahrams, sell alcohol and pork as per their choice?

Hassan Basri replied that:

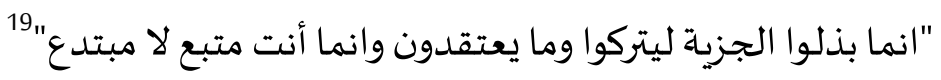

These minorities have accepted Jizya only because they are allowed to live according to their beliefs and your job is to follow the old way and not to invent a new way. You should also follow the Rightly Guided Caliphs in the case of these non-Muslim minorities because in the welfare state the Jizya is taken in the sense that non-Muslim minorities should be given full religious freedom in the matter of their religion".

\section{RIGHT TO HELP}

Welfare state helps the poor and needy non-Muslim minorities, through non-recreational benefits and establishes a chain of livelihood. It is the responsibility of the welfare state to ensure that no citizen of the Islamic state is deprived. The welfare of the poor is also the responsibility of the welfare state.

Almighty Allah says in the Holy Quran:

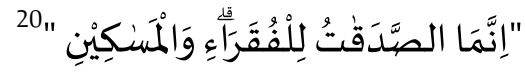

Indeed, alms are for the poor and for the needy.

In this sacred verse, the Faqir's are meant to be Muslims and Masakeen are meant to be the poor of Ahly-Kitab. Zakat is only the right of Muslims

\footnotetext{
${ }^{19}$ Ahkamu Ahluzimah:V1,P, 869

${ }^{20}$ AlQuran:9/ 256
} 
The Scholar Islamic Academic Research Journal

Vol. 7, No. 2 || July-December 2021 || P. 36-57

https://doi.org/10.29370/siarj/issue13ar3

but voluntary alms can be given to both Muslims and Non-Muslims so that the poor and needy can meet their necessities.

Hazrat Jabir bin Zaid said:

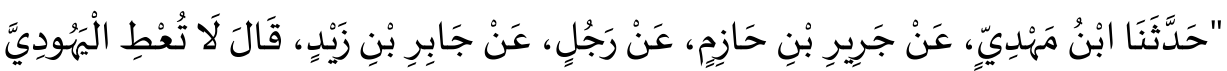

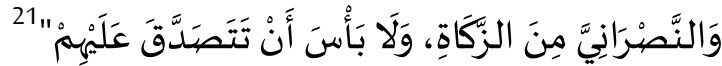

Do not give zakat to a Jew and a Christian, and it is okay for you to give alms (Sadqa) to them.

Once Hazrat Umer was on patrol, when he saw a blind man begging. He asked him "which group of people of the book do you belong to? Blind man replied that he is a Jew. He asked him why he came to beg. He replied to pay the jizya and to put out the fire in his stomach. Upon hearing, Hazrat Umer took his hand and brought it home and paid what he had and wrote to the servant of the treasury and said: "Investigate other such needy people as well. By God, it is not fair that their youth and old age should be spent on paying Jizya to us and we should leave them to beg". For such old people, Hazrat Umer forgave their Jizya and fixed a stipend for them from the treasury. ${ }^{22}$

The era of the righteous Caliphate was a practical example of a welfare state after Hazrat Muhammad (SAW), in which Muslims cooperated with poor and needy non-Muslim minority. It was officially declared that the

${ }^{21}$ Abu shaiba, Abu baker bin Abdullah, Almusanif fil Hadith,V. 2, P. 4

${ }^{22}$ Saharvi, Hifzurahman, Islam ka Iqtasadi nizam,Publisher Shaikul Hind Acadamy Krachi,P151 
The Scholar Islamic Academic Research Journal

Vol. 7, No. 2 || July-December 2021 || P. 36-57

https://doi.org/10.29370/siarj/issue13ar3

Jizya should be waived from old and needy minorities and the NonMuslims should be helped from treasury so that they would not beg due to economic weakness and would not reach out to anyone. So that they can make a living and be able to do and be free from worries.

\section{DUTIES OF MINORITIES}

Just as non-Muslim minorities have been given rights in a welfare state, they also have some duty that they need to fulfill. Just as the state must ensure that their rights are respected. It is also important for them to ensure that their duties are performed.

The order of duties to minorities is as follows:

1. Payment of Jizya and Khiraj.

2. Taking care of Islamic norms and sentiments.

\section{PAYMENT OF JIZYA AND KHIRRAJ}

Jizya is an annual tax per individual, which is levied on the men of the able bodied non-Muslim minorities and it applies to every person according to his means while poor Zimmi are completely exempt from it. No tax is levied on them as Jizya and there is also no limit to the amount but it is done upon the discretion of the state. And its necessity is because of order of Almighty Allah.

Almighty Allah says in the Holy Quran:

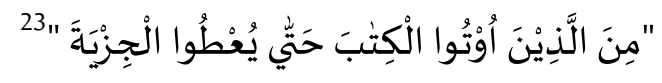

From those who were given the books so that they should give jizya.

${ }^{23}$ Al-Quran:9/29 
The Scholar Islamic Academic Research Journal

Vol. 7, No. 2 || July-December 2021 || P. 36-57

https://doi.org/10.29370/siarj/issue13ar3

Jizya is levied on three classes and khiraj on land is given according to the power and production of land. The amount of Khiraj also varies due to the differences in the productive capacity of the land. Sometimes, the amount is one dirham on one Qafeer, sometimes five dirham and sometimes ten. There must be a difference in the amount of tax levied, which is in fact a khiraj and there should also be a difference in the amount of eligibility and power of the person paying the jizya.

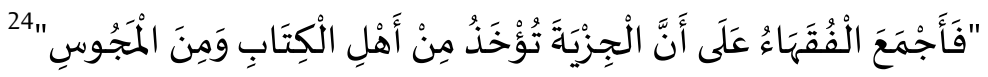
All the jurists unanimously agreed that the jizya should be taken from the People of the Book and from the Magi.

One of the main reasons why Jizya has been made obligatory for nonMuslims is because they are free from performing any defense duty. Islam has made it obligatory for its followers to defend the state, but has forgiven non-Muslims from such responsibility. Only cooperation with the Mujahedeen is required. And the reason why minorities are not given the service of fighting is because asking a person to sacrifice his life for the ideology for which they do not believe in is not fair. While to defend the state, a Muslim must fight, because the Islamic state is the name of an ideological state that has its own ideology. It is unreasonable to make it necessary to ask them to fight for an ideology which they does not believe in.

\section{TAKING CARE OF ISLAMIC NORMS AND MANNNERS}

Non-Muslim minorities should refrain from actions that insult the Holy Prophet (SAW), the Quran or might hurt the feelings of Muslims, such

${ }^{24}$ Ibn qayem, Jozi,Mummad bin abu baker,Ahkamu Ahluzimah, V1, P 141 
The Scholar Islamic Academic Research Journal

Vol. 7, No. 2 || July-December 2021 || P. 36-57

https://doi.org/10.29370/siarj/issue13ar3

actions are not allowed at all. Openly drinking alcohol, buying and selling it, eating pork with Muslims is also not permissible at all, as it is harm for Muslims and their state. Besides, there is no coercion on Non-Muslims them because it is against the rules of a welfare state. Islam is the only religion that does not impose its ideology on anyone. However, even if someone wants to convert after listening to the guidance, it encourages them to reach his destination on its own and give him time to think.

Almighty Allah says in the Holy Quran:

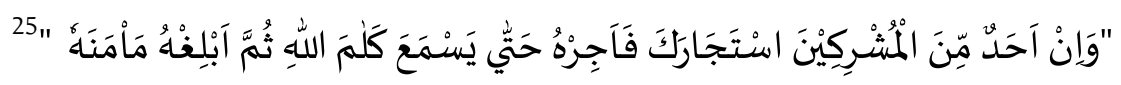

And if one of the polytheists seeks protection (shelter) from you, grant him protection until he hears the word of God. Then send them to their safe place.

This is known from the holy verse that if a non-Muslim, asks for shelter, give him peace for a while. This also shows that, Mustamin is also safe in Dar-ul-Islam like Zimmi. Mustamin cannot be killed nor his property taken from him. After passing of his time, he should be safely removed from Dar-ul-Islam. Islam gives protection to Mustamin and Zimmi.

\section{CURRENT STATE OF IMPLEMENTATION:}

Minorities have full rights and duties in the welfare state. In order to fulfill these rights and duties towards minorities, especially in the present times, government should take keen notice and numerous steps. In the Quran and

${ }^{25}$ Al-Quran:9/6 
The Scholar Islamic Academic Research Journal

Vol. 7, No. 2 || July-December 2021 || P. 36-57

https://doi.org/10.29370/siarj/issue13ar3

Hadith, the lives and property of minorities, their honor and dignity, and right to charity, are deeply acknowledged and guided.

There is a dire need to implement all the rights and obligations that Islam has taken on regarding minorities. Welfare state should be the one that takes appropriate measures to protect minorities and put them into practice. First and foremost, minorities should be allowed to worship and celebrate their religious festivals in accordance with their religious beliefs. Closing temples and churches or failing to provide adequate security, is in no way compatible with the welfare state. The Islamic Welfare State protects the heritage, even if it belongs to another religion or faith.

Inter faith harmony should be restored by the state. In order to do so an institute should be developed that over sees all the issues faced by the minorities. That can help them and guide them is there problems. This institute can implement the true Islamic values regarding minorities and non-Muslims. This in turn will reduce the harshness found in our extreme modern society regarding other religions and minorities.

In the Islamic Welfare State, it is very important to establish such a welfare institution to help the poor and needy minorities as well. This institution should have the support of Muslims and non-Muslim prosperous families and the government, so that welfare institution can grow rapidly which helps the poor non-Muslims. Non-Muslims can be given a chance to live a good life by helping them out of the voluntary alms given to Muslims in the welfare state. Minorities are an important pillar of the welfare state. Providing them with education and employment facilities is the duty of the government. Their quota in government jobs should be higher so that they can get as many good jobs as possible. By 
The Scholar Islamic Academic Research Journal

Vol. 7, No. 2 || July-December 2021 || P. 36-57

https://doi.org/10.29370/siarj/issue13ar3

taking care of the rights and duties of minorities, a welfare state can get

prosperity in every possible way.

\section{CONCLUSION:}

The Islamic welfare state is a blessing from Allah Almighty for the believers as well as for the minorities, in which they have all the rights that Muslims have. The state guarantees the protection of all rights whether they relate to religious duties or to the discipline of the state and to the fundamental human rights of citizens. The state ensures justice and equality between non-Muslim minorities and Muslims. Such minorities, who do not fight against the state on any front, have all these rights and the state ensure the protection of their lives, property and honor in every possible way.

Similarly, it is important to protect the rights of non-Muslim minorities because the Islamic welfare state is a state based on the principle of the Quran and Sunnah. Islam is a complete code of life and conduct that contains injunctions pertaining to every sphere of life. The state has a complete manifesto on minorities in which, they can live as they wish; they deserve an environment to perform their religious duties and have rights in marriages and death which they can perform as per their religion. The needy and helpless non-Muslim and their women are also the state's responsibility.

In a welfare state, non-Muslims are not burdened beyond their means. In a just state, they are given all the necessary political, social and economic rights and are given certain duties that must be fulfilled. Non-Muslims are completely free to live with their religious identity and live a full life 
The Scholar Islamic Academic Research Journal

Vol. 7, No. 2 || July-December 2021 || P. 36-57

https://doi.org/10.29370/siarj/issue13ar3

according to their own ways. Adoption of all these basic guidelines of the Islamic welfare state in the contemporary world can insure prosperous lives to all the minorities.

\section{(1) (8)}

BY NC SA This work is licensed under a Creative Commons

Attribution-NonCommercial-ShareAlike 4.0 International (CC BY-NC-SA 4.0) 